\title{
Residents' Attitudes towards the Built Environment in Historic Parklands in Nairobi, Kenya
}

\author{
Njiiri Wallace1*, Mugwima Bernard1, Karanja Dennis ${ }^{2}$ \\ ${ }^{1}$ Center for Urban Studies, Jomo Kenyatta University of Agriculture and Technology, Nairobi, Kenya \\ ${ }^{2}$ Department of Landscape Architecture, Jomo Kenyatta University of Agriculture and Technology, Nairobi, Kenya \\ Email: *njiiri.wallace@jkuat.ac.ke
}

How to cite this paper: Wallace, N., Bernard, M., \& Dennis, K. (2020). Residents' Attitudes towards the Built Environment in Historic Parklands in Nairobi, Kenya. Current Urban Studies, 8, 141-155.

https://doi.org/10.4236/cus.2020.82007

Received: February 10, 2020

Accepted: April 4, 2020

Published: April 7, 2020

Copyright $\odot 2020$ by author(s) and Scientific Research Publishing Inc. This work is licensed under the Creative Commons Attribution International License (CC BY 4.0).

http://creativecommons.org/licenses/by/4.0/ Open Access

\begin{abstract}
Contemporary attitudes shaping urban areas are not always sympathetic to the historic character of built heritage, meaning heritage contexts are subject to loss of scale, visual quality and associated values. This study sought to identify attitudes associated with this built heritage in order to establish community values necessary for the urban conservation of Historic Parklands in Nairobi. The Cultural Worldview (CV) scale was used to assess attitudinal preferences for the built environment among 302 respondents who were asked to rate 32 statement items on a 7-degree Likert scale designed for responses. Statements with shared variances were grouped together under factor analysis and the degree of variability within shared variances distilled 3 attitudinal preference dimensions. From the rated attitudinal statements, the identified preference dimensions included the following; One, cultural heritage loss which scored a high mean of 5.29 perceived as the disappearance of architectural, historic and aesthetic values. Two, cultural heritage recognition which scored a mean of 4.79 confirming that heritage assets were acknowledged as important legible site markers. Three, cultural heritage linkage which scored a mean of 4.34 supported by the perceived associational, cultural and social values. This study recommends three action points. First, a heritage monitoring database that assigns the priorities of preservation, rehabilitation and adaptive-reuse to mitigate cultural heritage loss. Second, buffer zones to classify and protect recognized built heritage from unplanned urban growth process. Third, a heritage walk to foster the interactions between residents, visitors and the host place in order to reinforce the interpretation qualities of built heritage responsible for enhancing history, community values and collective identity.
\end{abstract}

\section{Keywords}

Cultural Heritage, Attitudes, Values, Urban Conservation 


\section{Introduction}

The scope of conservation of built heritage ranges from town planning of entire urban heritage areas to the preservation or consolidation of a crumbling artefact. According to the Burra Charter (Australia ICOMOS, 1999), conservation may, depending on circumstances, include the processes of maintenance, preservation, restoration, reconstruction, adaptation and often includes a combination of more than one of these.

Contemporary theory of conservation calls for sensible actions as a way of maintaining and reinforcing the uses, meaning and values of historic objects (Vinas, 2005). However, conservation as a process can only exist if, firstly, society attributes values to the urban structure and secondly, the process of valuing an object results from operations involving comparison among objects which may gain or lose their values during the period of their material existence (Jokilehto, 2007). Value as category of thought is necessary for any process of comparison of things of the same or different kind, with reference to the realization of choices based on objective criteria.

Riegl (1982), argues that the identification of cultural values in relation to urban structures happens mainly through the use of symbolic systems of reference, such as history, aesthetics or, quite simply, age associated with the process of forming images, memories and representations in a given society. However, the dominance of one type of value over the other does not determine the form and degree of conservation; rather, the relative assessment of several values, a kind of social calculus that determines the extent and the degree of conservation (Zancheti \& Jokilehto, 2014). It is therefore, important to make transparent this process of assessment.

Van Oers \& Pereira Roders (2012), have pointed to the loss of tangible heritage as a precursor to damage of associated intangible cultural heritage and the subsequent loss of the social meaning of places. Intangible heritage in this context, the narratives and emotions associated with built heritage is an important aspect of understanding places. Heritage then is not a thing or artefact, but the set of values and meanings that a community derives from the artefacts, the experience and linkages to host the community.

Lately in Kenya, urbanization has not been gradual but intermittent and drastic, meaning the erosion and abrasive disruptions pointed out above are even more amplified. Locally, the urban heritage of the city of Nairobi, specifically, its historic neighbourhoods such as Parklands, is under a great threat of loss due to the rapid urbanization and economic pressure that has been used to justify demolition of built heritage in favour of new development.

Contemporary construction has invaded and supplanted local vernaculars and, consequently, adversely affected historic character, visual quality and associated values. The loss of historic townscape character is exemplified by incompatible contemporary additions adjacent to built heritage as observed on Second Avenue in Parklands shown in Figure 1. Additionally, the inappropriate use of 
contradicting forms and materials for new construction has reduced the historic and visual quality of built heritage as observed in Figure 2 and Figure 3 respectively.

Interventions in this heritage context by designers and decision-makers, have not critically evaluated the appropriateness of contemporary forms, materials and layouts with regard to existing urban morphologies, typologies, cultures, practices and values. The urban conservation of site-specific qualities and attributes as part of contemporary construction in this heritage landscape, therefore, is a complex design challenge that merits some guidance.

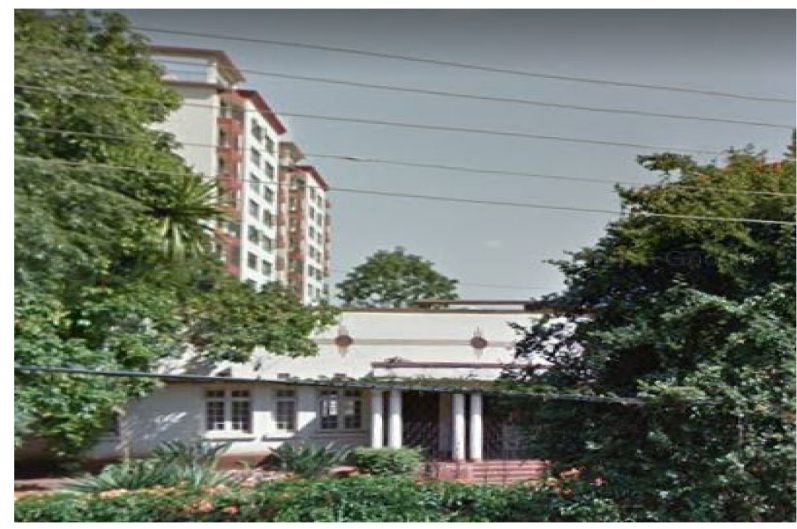

Figure 1. Loss of urban scale on 2nd avenue Parklands.

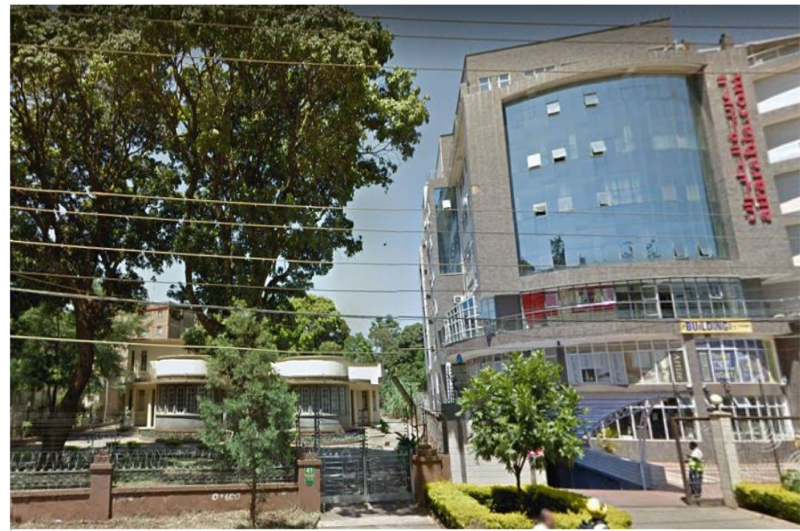

Figure 2. Loss of historic quality on 3rd avenue Parklands.

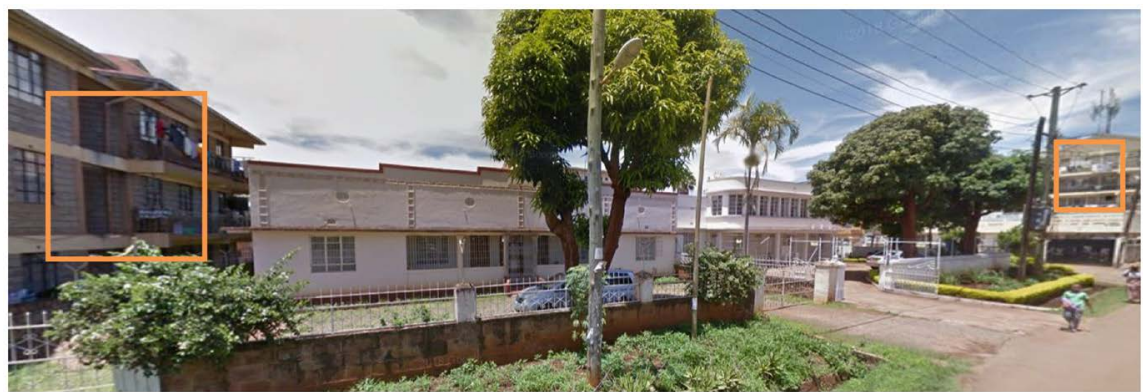

Figure 3. Loss of visual quality on 4th avenue Parklands. 


\section{Literature Review}

No society makes an effort to conserve what it does not value. Understood as efforts to maintain and enhance cultural heritage significance. De la Torre (2013) states that all conservation decisions are the product of a series of value judgements and that value has always been the reason underlying heritage conservation.

Fielden (2003) has grouped values attributed to cultural heritage into three broad categories; emotional, cultural and use values. Firstly, emotional values include wonder, identity, continuity, spiritual and symbolic. Secondly, cultural values include documentary, historic, archaeological, age, scarcity, aesthetic, architectural, townscape and landscape, ecological, technological and scientific. Thirdly, use values include functional, economic, social, educational, political and ethnic. An analysis of these values should result in a statement of the significance of the cultural property.

According to Schofield (2009), an effective value typology for urban heritage must have the capacity to symmetrically group similar values that are expressed differently in order to create common expressions of significance for all stakeholders. Khalaf (2016), defines the values-based approach as one that seeks to identify, sustain and enhance cultural heritage significance, understood as the overall value of heritage, or the sum of its constituent heritage values. Specific to this approach is the emphasis on understanding how the heritage in question is valued, often formalised in a statement of significance, in order to manage, use and conserve it appropriately.

However, the consensus called for in the Contemporary Theory of Conservation includes everyone for whom the object has any meaning. The user of the object is any person for whom the object performs any function, be it tangible or intangible and conservation decisions should bear in mind that it is the subjects and not the objects for which any conservation process is carried out (Vinas, 2005). It is therefore necessary to have a definite reference point for measuring, articulating and justifying the case for suggesting that a particular place is important and should be protected.

Kaplan and Kaplan (1982), argue that environmental perception studies can provide an understanding of how people behaviour can be influenced by the environment and vice versa. In identifying values in the built environment, Najd et al. (2015), have highlighted the wide use of preference approach in environment perception studies and its validity and acceptability as a method in uncovering underlying factors affecting perceptions such as attitude, content and spatial configuration of the particular landscape. Therefore, it can be concluded that people's evaluation of the built environment relates to their affective responses and judgements which provide an articulation of the values of a place that inform decision making in the context of value driven management.

\section{Methodology}

In this study, a standard questionnaire for assessing attitudinal preferences to- 
wards the built environment in historic Parklands in Nairobi was adopted. This data collection tool shown in appendix I comprised of 32 attitudinal statements designed to better understand how residents perceived their built environment based on the Cultural Worldview (CV) scale, developed by Choi \& Fielding (2016).

The factors constituted in the (CV) scale adopted in this study included linkage, recognition and loss of built heritage comprising of a sum of 32 items. For this study, the content included general beliefs about the value of built heritage buildings, visual qualities and the relationship between preservation and economic development with regards to the extent to which people have been negatively affected by the loss of built heritage.

The target population comprised of 37,505 residents of Parklands constituency in Nairobi and the demographic characteristics of the sample shown in appendix II are as per the census figures in the Gender, Age group, Demographic Indicators and Households Size by County, Constituency and Wards (KNBS \& SID, 2013). Kothari (1985), in determining the sample size, suggests

$$
n=N_{o} /(1+N)(e)^{2}
$$

where,

$$
\begin{aligned}
& n=\text { sample size; } \\
& N=\text { population size; } \\
& e=\text { acceptable sampling error }(5 \%) \text { at } 95 \% \text { confidence level. } \\
& \text { Thus, } \\
& \qquad n=37505 /(1+49381)(0.05)^{2} \\
& n=302 .
\end{aligned}
$$

\section{Study Area}

The original Parklands district lies directly north of Nairobi CBD, on the first bluff of the highland area above the Nairobi River. Along this bluff runs Parklands Road, forming the southern boundary of the district. Above Parklands Road, six streets named First through Sixth Parklands Avenue run approximately east to west each in two long blocks.

The overall scheme is roughly rectangular, about one square kilometre in area and the coordinates of Parklands are: $01^{\circ} 15^{\prime} 36^{\prime \prime} \mathrm{S}, 36^{\circ} 49^{\prime} 05^{\prime \prime} \mathrm{E}$. Architecturally, in choosing an up-to-date style conspicuously different from the Cotswold cottage and country house patterns aped by the white settler community, the Asian bourgeoisie often built in art deco and moderne styles. The Indian non-registered architects took advantage of the already well-established links with the Indian diaspora to modify buildings by introducing new elements of form evident in built heritage in Parklands as documented in Figure 4.

However, owing to its proximity to Nairobi's CBD, increased demand in Parklands for commercial activities surpassed by the supply delivered by planning agencies has triggered the demolition of built heritage in favour of new construction. Moreover, there is a dire necessity for the sympathetic care and conservation 


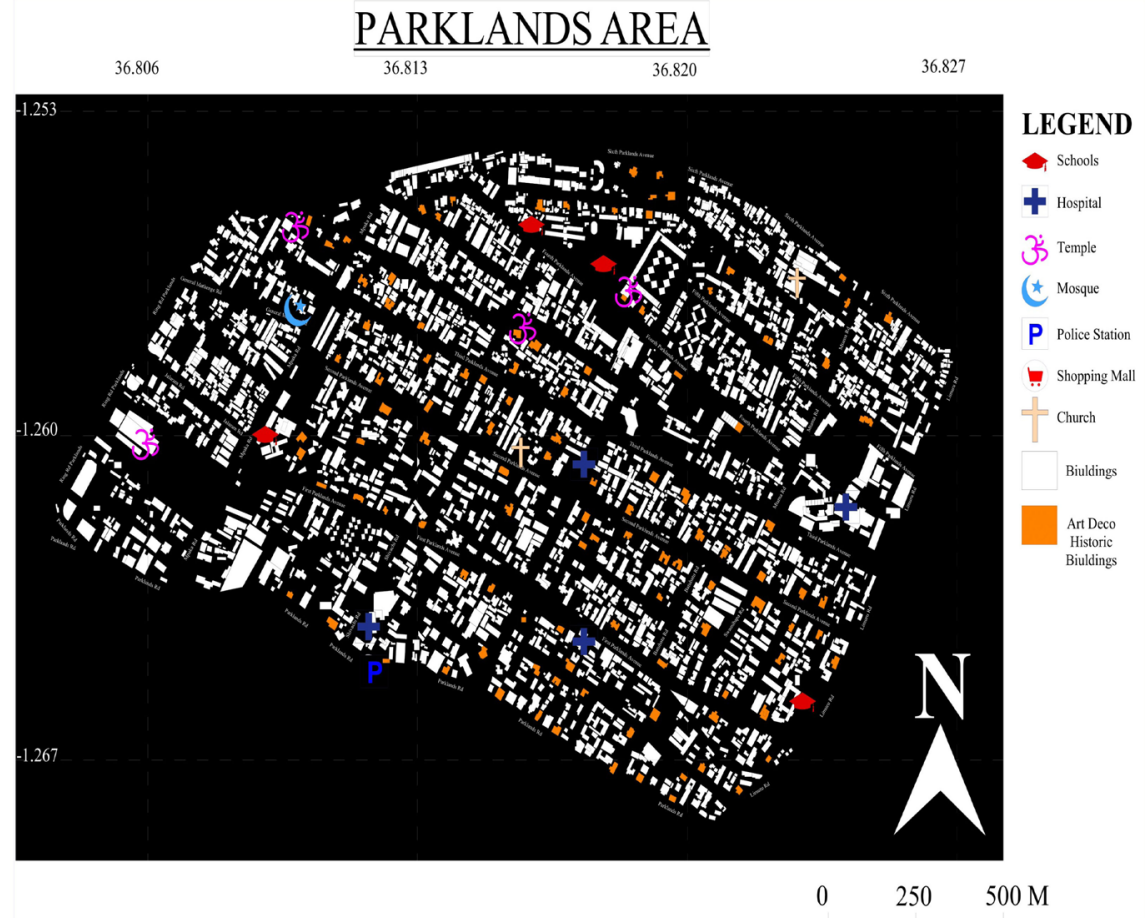

Figure 4. Built heritage comprising of art-deco buildings in Historic Parklands.

of architectural heritage that hence causes a conflict to arise. Attempts to generate revenue by local authorities by allowing the approval of contemporary construction in historic Parklands while sparing historic and old ordinary buildings is not only against conservation ethics as far as the authenticity and cultural setting of the site is concerned but a disregard for community values associated with built heritage.

Architectural heritage in the historic area is increasingly neglected in a speculative property market that has left it under ill maintenance as shown in the examples on Wambugu drive and Parklands road shown in Figure 5 and Figure 6 respectively. Large-scale real estate development in and around the historic neighbourhood is characterized by a huge rise in land prices that has induced a tendency in owners of old buildings and land properties to negotiate with real estate developers for contemporary architectural development shown in the examples in Figure 7 and Figure 8 with respective economic profit realised through joint ventures.

\section{Factor Analysis for Attitudinal Preferences}

To assess the attitudinal degree to which the $\mathrm{n}=302$ sample of respondents had towards the built environment and the 32 statement items being the variables of focus, the need to identify the ones contributing significantly was paramount. In SPSS, different variables were grouped differently, based on Eigen values greater than 1 and shared variances. 


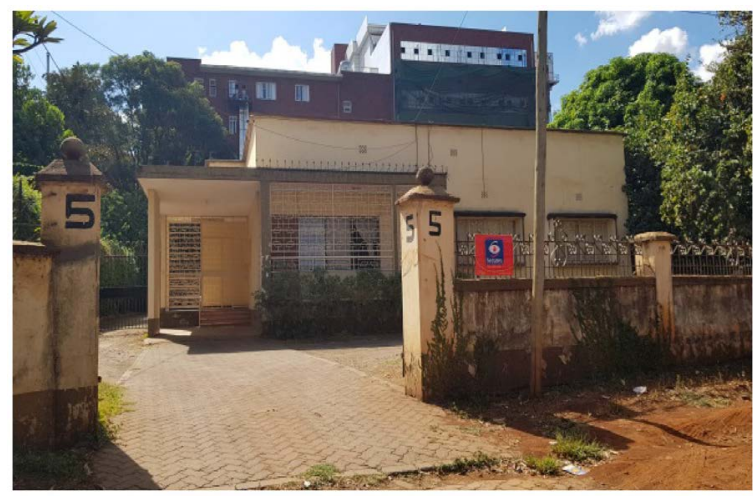

Figure 5. Neglected built heritage on Wambugu drive.

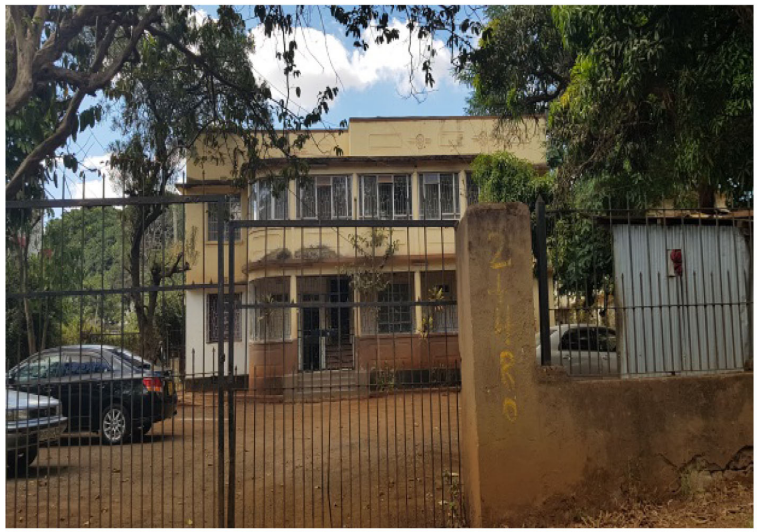

Figure 6. Neglected built heritage on Parklands road.

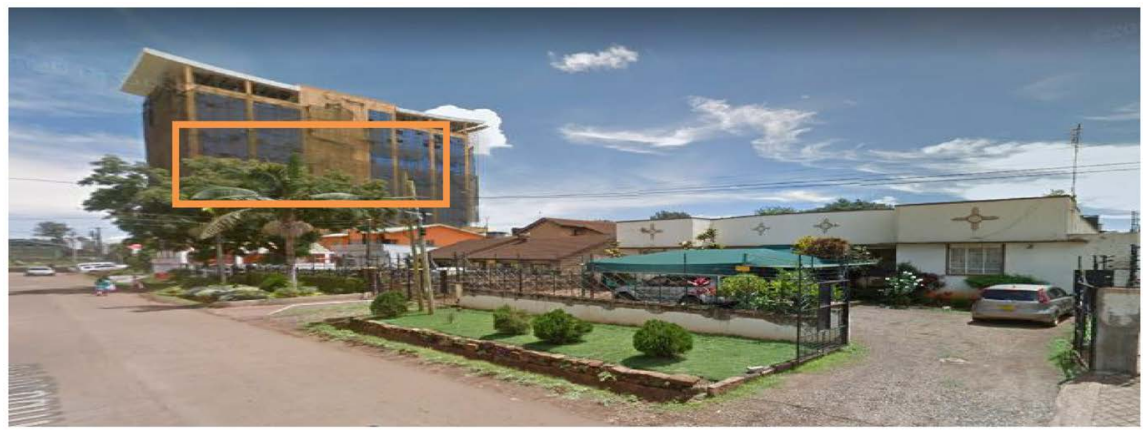

Figure 7. Insensitive contemporary infills on 6th Avenue Parklands.

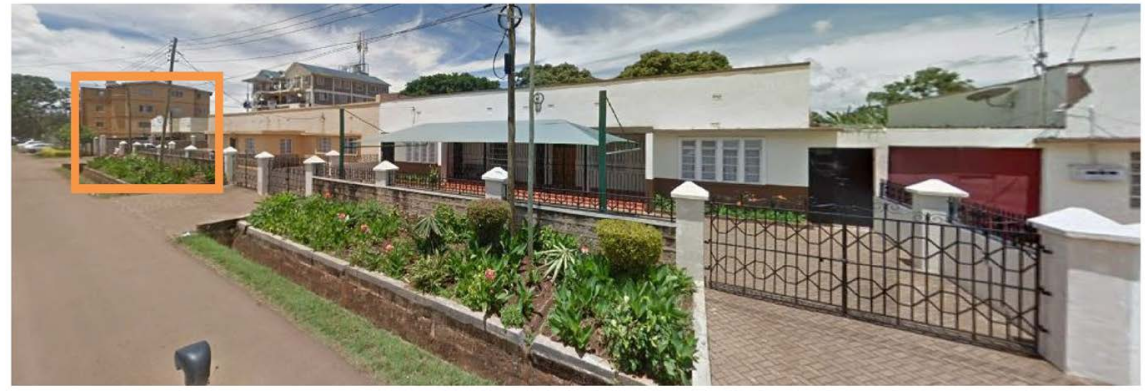

Figure 8. Land-use incompatibility on 5th avenue Parklands. 
To check the variables with low factor scores that needed to be eliminated from the analysis, anti-image correlation matrix was used. In processing data, variables with scores of less than 0.5 in the main diagonal were expunged, as this destabilized the loadings. Thus from the analysis, 27 variables were derived according to "eigenvalue greater than one" criterion with 10 factors emerging which accounted for 54.361 per cent of the total variance explained.

Additionally, the Varimax method of extraction of factors was employed which produced uncorrelated (independent) factors that eliminated the problem of variables being too highly correlated. The Kaiser Meyer Olkin (KMO) of 0.676 was obtained which ranged between 0 and 1 as shown in Table 1 . The closer the value to 1 , the more logical factor analysis informed the sense of sample adequacy.

The determinant of the correlation matrix was 0.073 which was greater than the recommended minimum value of 0.00001 indicting that that factor analysis could be conducted on the dataset. This being an exploratory procedure, a finite, pre-determined number of factors could not be obtained. However, from the maximum convergence, 10 factors were obtained. Factors numbered 1, 2 \& 6 had a significantly reasonable number of variables clustering around the centroids. Hence, in determining the attitudinal preferences of the built environment in historic Parklands in Nairobi, the three factors below took precedence in the data findings with the remaining factors bearing insignificant contributions, with at most two variables anyway.

\section{Attitudinal Preference Dimensions}

According to Choi \& Fielding (2016), measurement scales normally include equal numbers of positively and negatively stated items in order to avoid agreement bias. Consequently, the 32 item standard questionnaire comprised of both pro-cultural statements in favour of preserving cultural heritage resources as well as anti-cultural statements opposed to preserving cultural heritage resources. Principal component analysis revealed three preference dimensions that included sum of 12 attitudinal statements. The detailed description of results for each factor is shown in Table 2 below.

1) Linkage to Built Heritage

Linkage to built heritage comprised of five statements as shown in Table 2 above with the average mean score of 4.34 which was somewhat preferable on

Table 1. KMO and Bartlett's test.

\begin{tabular}{lcc}
\hline \multicolumn{2}{c}{ KMO and Bartlett's Test } \\
\hline Kaiser-Meyer-Olkin Measure of Sampling Adequacy & 0.676 \\
Bartlett's Test of Sphericity & Approx. Chi-Square & 762.860 \\
& Df & 351 \\
\hline
\end{tabular}


Table 2. Attitude preference dimensions.

\begin{tabular}{|c|c|c|c|c|}
\hline & Factor 1: Linkages & Loading & Mean & Mean Score \\
\hline 1 & Old buildings are a legacy from past generations & 0.624 & 5.71 & \\
\hline 3 & $\begin{array}{l}\text { My grandchildren do not have a right to inherit } \\
\text { historic buildings }\end{array}$ & 0.582 & 2.37 & \\
\hline 5 & Importance attached to old buildings is inadequate & 0.544 & 5.22 & 4.304 \\
\hline 6 & $\begin{array}{l}\text { New buildings give information on historic past } \\
\text { experiences }\end{array}$ & 0.504 & 2.44 & \\
\hline \multirow[t]{2}{*}{7} & Old buildings are a reflection of social identity & 0.410 & 5.78 & \\
\hline & Factor 2: Recognition & Loading & Mean & Mean Score \\
\hline 10 & Details on old buildings provide artistic inspiration & 0.699 & 5.22 & \multirow{4}{*}{4.795} \\
\hline 14 & $\begin{array}{l}\text { Traditional building craft used in old buildings } \\
\text { is a rare skill }\end{array}$ & 0.648 & 5.19 & \\
\hline 23 & $\begin{array}{l}\text { Local governments should prevent demolition } \\
\text { of historic buildings }\end{array}$ & 0.454 & 5.55 & \\
\hline 32 & $\begin{array}{l}\text { Tax paid should be used to preserve privately owned } \\
\text { historic places }\end{array}$ & 0.442 & 3.22 & \\
\hline & Factor 3: Loss & Loading & Mean & Mean Score \\
\hline 2 & I am saddened by the demolition of historic buildings & 0.578 & 5.32 & \\
\hline 19 & Increase in car use negatively affects pedestrians & 0.541 & 5.36 & 5.29 \\
\hline 26 & Unplanned urbanization harms historic neighbourhoods & 0.489 & 5.19 & \\
\hline
\end{tabular}

the 7 degree Likert scale. This finding is supported by the perceived connectedness between people of different generations which reflects historical meaning and significance attached to build heritage. Furthermore, the detection of urban change attributed by contemporary development and its role in relaying past experiences scored a low mean of 2.44 under item 6 as shown in Table 2. This confirms that residents considered the value of built heritage and the need to preserve it for historical legacy and posterity.

2) Recognition of Built Heritage

Recognition of built heritage was the second highest attributer of preferences towards the built environment supported by the mean score of 4.79 which was somewhat preferable on the 7 degree Likert scale as shown in Table 2. The perceived recognition of diverse heritage values in the built environment such as architectural, historic townscape, aesthetic, rarity and age values backed up the high preference scores rated for authenticity. This finding confirms that integrity increases value of built heritage as a source of historical information whose material is genuine, its craft rare and has aged over time respecting the contributions of all its periods.

3) Loss of Built Heritage

Loss of built heritage was the highest attributer of preferences towards the built environment supported by the mean score of 5.29 which was somewhat 
preferable on the 7 degree Likert scale as shown in Table 2. This was due to the perceived disappearance of associational, architectural, historical and ecological values attributed by the demolition of built heritage. Additionally, increase in vehicular use, fragmented urban greenery and unplanned high rise contemporary development that has replaced built heritage was a reducer of landscape preferences supported by high mean scores.

\section{Recommendations for Built Heritage in Historic Parklands}

In the context of the above conclusion on loss, linkage and recognition of built heritage in historic Parklands, it is extremely useful to point out some recommendations and solutions to manage change in the urban heritage landscape.

The need for preservation of the historic quality identified among residents in Parklands identified from their attitudes associated with built heritage may be interpreted as residents' intentions for positive behavioural actions that impact their built environment. In the following section, some of the ideas to enhance the overall urban system in historic Parklands that balance the conservation of the existing built heritage and the sufficient planning of future contemporary urban fabric are highlighted.

\section{1) Heritage Monitoring Database}

As a first step, it is important to develop a complete GIS-based documentation system that includes detailed information for each heritage building including its geographic location, parcel number and ownership, construction date, number of floors, construction material, current building status and current building use.

Such a database provides a starting point for a decision making and monitoring system of the heritage buildings' status and assigns the priorities of rehabilitation and maintenance for built heritage to mitigate the loss of historic character. Where possible, this geodatabase can be the basis for creating buffer zones to classify and protect threatened built heritage from the unplanned and insipid urban growth process.

\section{2) Special Area Reservation}

This study proposes special area reservation as one strategy to relate architectural heritage buildings with compatible contemporary development that respects the character of its historic context, for which several pointers are listed including; use, scale, style, silhouette, massing, alignment, surface articulation, window to wall ratio and window proportions summarized under development and design guidelines.

From this point of view, the positive perception for built heritage as sought by this study, may infer to positive user behaviour. Moreover, to enhance the visitor experience is to consequently ensure public support and awareness of heritage conservation with its various degrees of intervention that include conservative surgery, preservation, rehabilitation and adaptive re-use.

\section{3) Place Branding}

A definitive argument for the introduction of special treatment in selected and 
sensitive areas such as the heritage image zone on First, Second and Third Avenues in historic Parklands are recommended. This includes the restoration of dilapidating art deco heritage buildings, modification of neglected buildings for conversion and adaptive reuse. This recommendation is based on a highly visual story with which to make a historic Parklands desirable, not only for tourism promotion purposes, but also with the intention of highlighting built heritage, verdant public spaces, mixed land-use patterns and religious centres such as mosques and temples.

\section{Conclusion}

This study has exposed favorable attitudes Parklands residents have towards their built environment, majority holding built heritage as a community asset and its preservation as an important community service, even in comparison to other services considered important such as economic development. This builds on the residents' acknowledgement and recognition of built heritage as a reflection of collective identity, of people and place, nevertheless noting the inadequate attention given to heritage.

A curious finding is that residents oppose demolition of heritage by owners without legal restrictions, which points to wider community appreciation and ownership of collective heritage, not just properties they hold individually. The residents strongly argue for the public underwriting of privately owned heritage buildings via waivers and tax credits. In advocating for social engineering that enhances positive behavioural actions which support the needs of residents, designing contemporary development that is compatible with or similar to existing architectural heritage, which show a balanced distribution in the built environment can be constructed and one can refrain from creating urban spaces which are isolated from each other and hard to make sense of.

All the elements of an environment may show diversity and be different; however, such difference should be neither so intense that it becomes complex nor so low that it causes monotony. Between the elements, there should be an order to an extent that will not disrupt visual quality and a difference to an extent that will not disrupt subtle complexity.

Finally, one can be ensured that insipid non-conforming construction, nonplanned urbanization disrupting historic townscape character causes historic urban areas to lose their perceptibility and instead sympathetic and compatible structures that bring meaning to the environment reinforce the history, values and collective identity in heritage contexts.

In spite of the amount of literature reviewed on visual quality, it has been difficult to offer a full description of the nature of the experiential quality construct in a heritage context. Since a limitation of the current study was the use of local area residents in order to control for factors that predict preference, an expert panel and in-depth focus group interviews are recommended in future research for this aspect of the methodology. 


\section{Conflicts of Interest}

The authors declare no conflicts of interest regarding the publication of this paper.

\section{References}

Australia ICOMOS (1999). The Burra Charter, The Australia ICOMOS Charter for Places of Cultural Significance. Australia ICOMOS Inc.

Choi, S., \& Fielding, K. S. (2016). Cultural Attitudes WTP Determinants. Sustainability, 8 , 570 .

De la Torre, M. (2013). Values and Heritage Conservation. Heritage \& Society, 6, 155-166. https://doi.org/10.1179/2159032X13Z.00000000011

Fielden, B. (2003). Conservation of Historic Buildings. London: Architectural Press.

Jokilehto, J. (2007). International Charters on Urban Conservation: Some Thoughts on the Principles Expressed in Current International Doctrine. City Time.

Kaplan, S., \& Kaplan, R. (1982). Cognition and Environment: Functioning in an Uncertain World. New York: Praeger.

Kenya National Bureau of Statistics (KNBS) and Society for International Development (SID) (2013). Exploring Kenya's Inequality: Pulling Apart or Polling Together. County and National Reports.

Khalaf, R. W. (2016). Architectural Compatibility beyond the Eye of the Beholder. Journal of Cultural Heritage Management and Sustainable Development, 6, 238-254. https://doi.org/10.1108/JCHMSD-07-2015-0028

Kothari, C. (1985). Research Methodology Methods and Techniques. New Delhi: Wishwa Prakashan.

Najd, D., Ismail, N. A., Maulan, S., Mohd Yunos, M. Y., \& Dabbagh Niya, M. (2015). Visual Preference Dimensions of Historic Urban Areas: The Determinants for Urban Heritage Conservation. Habitat International, 49, 115-125.

https://www.elsevier.com/locate/habitatint https://doi.org/10.1016/j.habitatint.2015.05.003

Riegl, A. (1982). The Modem Cult of Monuments: Its Character and Its Origin, Oppositions.

Schofield, J. (2009). Being Auto Centric: Towards Symmetry in Heritage Management Practices in Valuing Historic Environments.

Van Oers, R., \& Pereira Roders, A. (2012). Historic cities as model of sustainability. Journal of Cultural Heritage Management and Sustainable Development, 2, 4-14. https://doi.org/10.1108/20441261211223298

Vinas, M. S. (2005). Contemporary Theory of Conservation. London: Elsevier.

Zancheti, S. M., \& Jokilehto, J. (2014). Values and Urban Conservation Planning: Some Reflections on Principles and Definitions. Journal of Architectural Conservation, 3, 37-51. https://doi.org/10.1080/13556207.1997.10785179 


\section{Appendix I}

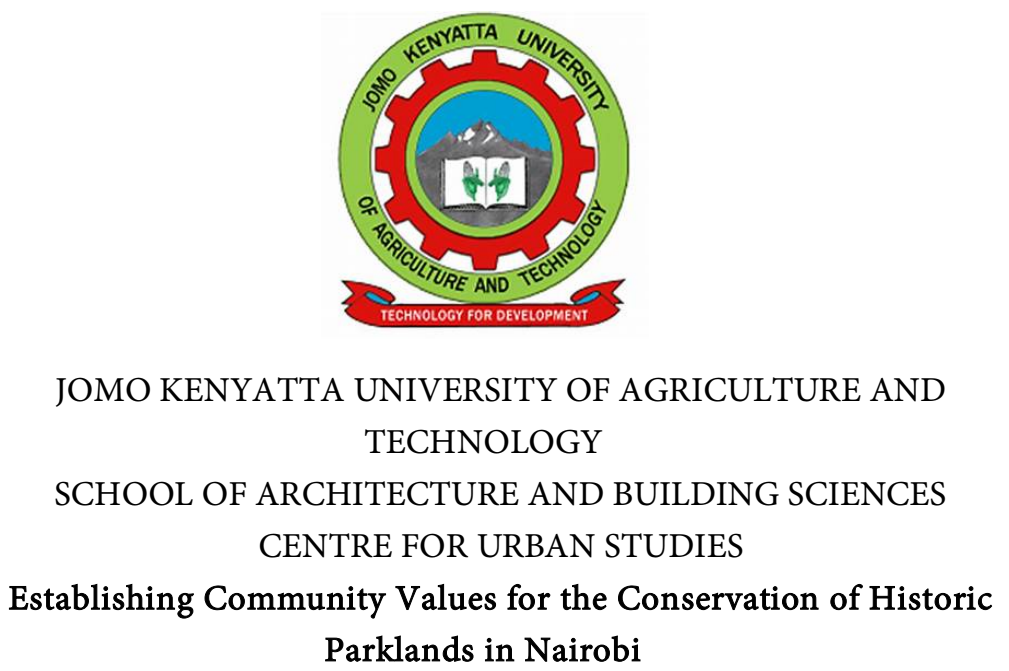

Attitudinal Study

You are invited to participate in a research study that only includes community residents who voluntarily choose to take part and for approximately 15 minutes. This exercise aims to understand your attitude and related interests regarding historic as well new buildings in Parklands constituency in Nairobi.

Declaration: The information given will be treated with confidentiality and used for academic purposes only and withdrawal from the study is allowed without penalty.

\begin{tabular}{cccc}
\hline & \multicolumn{3}{c}{ Kindly Tick on the Following Details Where Appropriate } \\
\hline Male & Age & Ethnicity \\
& Female & $18-24$ & Kenyan Asian \\
& Elementary & $25-34$ & Indigenous Descendant; \\
& High School & $35-44$ & [kikuyu, Kamba, luhya, luo] \\
Education & College & $45-54$ & Kenyan American \\
Level & Vocational & $55-64$ & Somali \\
& Bachelors Degree & $65+$ & Other \\
\hline
\end{tabular}

You are presented with a series of attitude statements on which you are asked to rate how much you like their appearance on a 7-point scale as follows: 7) strongly disagree $[\mathrm{SD}], 6)$ disagree $[\mathrm{D}], 5)$ mildly disagree $[\mathrm{MD}], 4)$ neutral $[\mathrm{N}]$, 3) mildly agree $[\mathrm{ML}], 2)$ agree $[\mathrm{L}], 1)$ strongly agree $[\mathrm{SL}]$. Please indicate the extent to which you agree with the following statements:

\begin{tabular}{|c|c|c|c|c|c|c|c|c|c|}
\hline \multicolumn{10}{|c|}{ Specific Objective 2: To Establish Values Associated with Built Heritage in Parklands } \\
\hline & & \multirow{2}{*}{ Attitudinal Statements } & 1 & 2 & 3 & 4 & 5 & 6 & 7 \\
\hline & & & $\mathrm{SD}$ & $\mathrm{D}$ & MD & $\mathrm{N}$ & MA & A & SA \\
\hline Identity & 1 & $\begin{array}{l}\text { Old buildings are a legacy } \\
\text { from past generations }\end{array}$ & & & & & & & \\
\hline
\end{tabular}




\section{Continued}

I am saddened by the demolition

of historic buildings

3 My great grandchildren do not have a right to inherit historic buildings

4

We do little to protect historic buildings in Nairobi Importance attached to old buildings is inadequate

New buildings give information on historic past experiences

Old buildings are a reflection of social identity Increase in the population of Deep Blue slums has caused insecurity

Aesthetic New building designs are complex to perceive

10 Details on old buildings provide artistic inspiration

11 Trees and hedges make Parklands memorable

12 Old buildings have a unique character

13 Materials used in old buildings give off a rustic effect

14 Traditional building craft used in old buildings is a rare skill

15 City park helps me in relieving stress from daily life

16 Poor maintenance of City park has caused its underuse

Advertisements in the area cause visual pollution

18 Highrise buildings do not infringe on privacy in old houses

19 Increase in car use negatively affects pedestrians

20 Open spaces in front of old buildings add to street attractiveness

Solid fences in new neighbourhoods enhance interaction

22 Setbacks applied in new buildings cause street congestion

23 Local governments should be able to prevent demolition of historic buildings

24 Walking on street in old neighbourhoods is preferable 


\section{Continued}

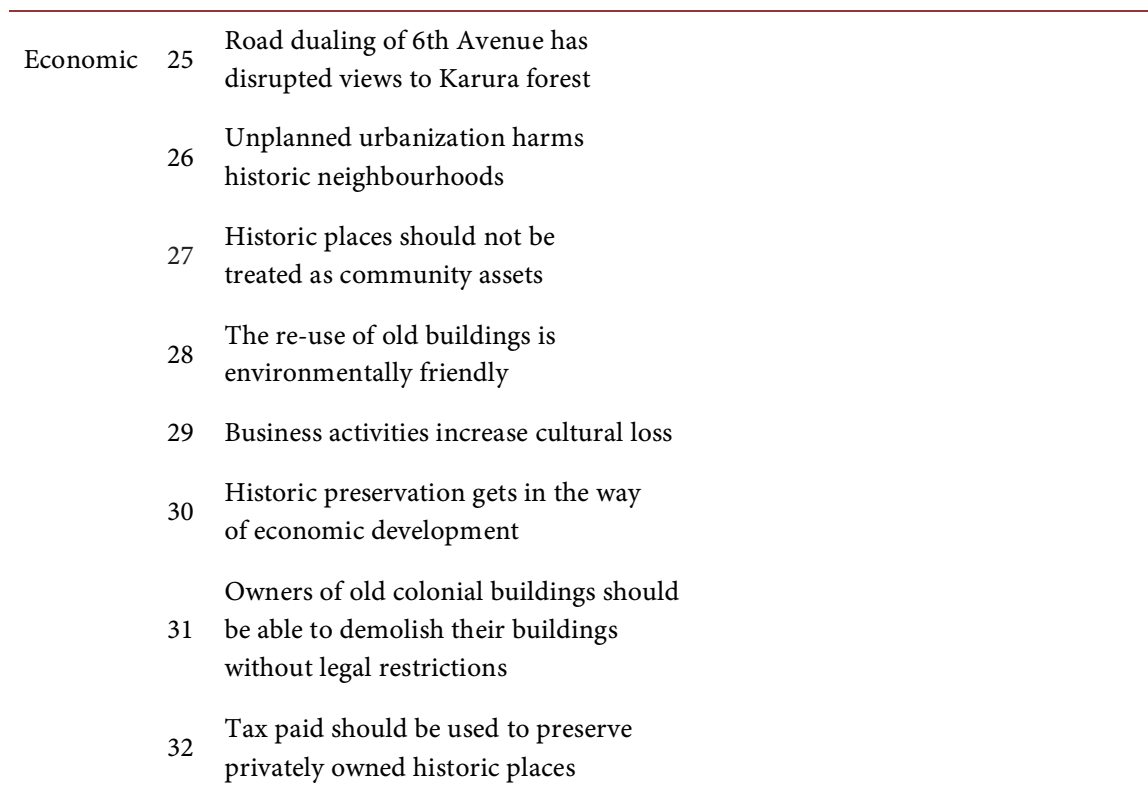

\section{Appendix II}

\begin{tabular}{|c|c|}
\hline \multicolumn{2}{|c|}{ Demographic Characteristics of the Research Sample in Parklands in Nairob } \\
\hline Total Population & 37,505 \\
\hline Males & 18,971 \\
\hline Females & 18,534 \\
\hline \multicolumn{2}{|c|}{ Age Group } \\
\hline $15-34$ yrs & 13,342 \\
\hline $15-64$ yrs & 26,915 \\
\hline $65+$ yrs & 2626 \\
\hline \multicolumn{2}{|c|}{ Demographic Indicators } \\
\hline Sex Ratio & 1.024 \\
\hline Total Dependency Ratio & 0.393 \\
\hline Child Dependency Ratio & 0.296 \\
\hline Aged Dependency Ratio & 0.098 \\
\hline \multicolumn{2}{|c|}{ Portion of House Hold Members (HH) } \\
\hline $0-3$ & 58.0 \\
\hline $4-6$ & 35.0 \\
\hline $7+$ & 6.9 \\
\hline Total & 11,207 \\
\hline
\end{tabular}

